
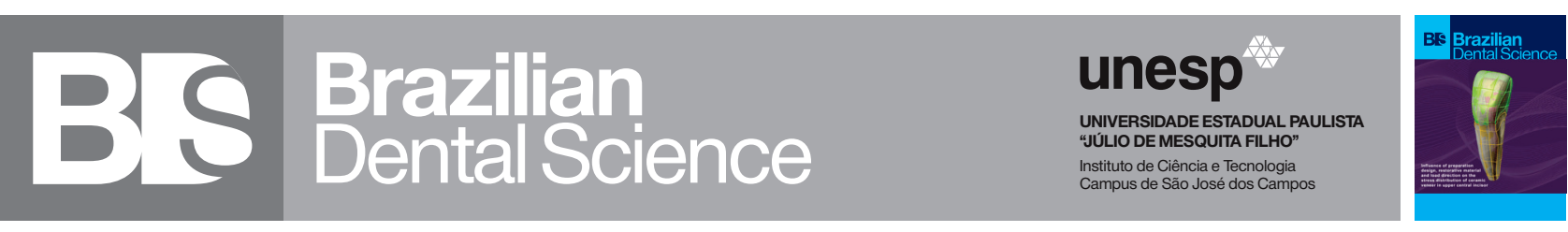

\title{
Influence of Preparation Design, Restorative Material and Load Direction on The Stress Distribution of Ceramic Veneer in Upper Central Incisor
}

Influência do desenho de preparo, material restaurador e direção de carga na distribuição de tensão de laminado cerâmico em incisivo central superior

Laura Célia Fernandes MEIRELLES ${ }^{1}$, Fernanda Zapater PIERRE ${ }^{1}$, João Paulo Mendes TRIBST ${ }^{2}$, Clovis PAGANI ${ }^{1}$, Eduardo BRESCIANI ${ }^{1}$, Alexandre Luiz Souto BORGES ${ }^{1}$

1 - São Paulo State University (UNESP), Institute of Science and Technology, Department of Restorative Dentistry, São José dos Campos, São Paulo, Brazil.

2 - University of Taubaté (UNITAU), Department Dentistry, Postgraduate Program in Dentistry, Taubaté, São Paulo, Brazil.

\section{ABSTRACT}

Objective: Evaluate the effect of four preparation designs, two ceramic materials, and two occlusion contact types on the stress distribution of ceramic veneer in upper central incisor. Material and methods: 3D-models were performed in the modeling software containing enamel, dentin, pulp, periodontal ligament and a base of polyurethane resin. The designs were modeled and exported to the computer aided engineering software to perform the static structural analysis. For the mesh, a total of 155429 tetrahedron elements and 271683 nodes were used, after a $10 \%$ convergence test. Two materials, lithium disilicate and feldspathic ceramics, were simulated. A static load of 100 $\mathrm{N}$ on $45^{\circ}$ was applied on the incisal and middle thirds of the palatal tooth region, guided by the occlusal plane. The base was constrained in all directions. The Maximum Principal Stress was the failure criteria chosen for the analysis. Results: The Finite Element Analysis showed that the most conservative designs presented less stress concentration on the ceramic veneer. However, the highest tensile stress concentrations were observed on lithium disilicate veneer with extend design, on the middle third. The type of occlusal contact presented different stress patterns among the preparation designs; the incisal contact showed higher stress concentration compared to middle third contact regardless the ceramic

\section{RESUMO}

Objetivo: Avaliar o efeito de quatro desenhos de preparo, dois materiais cerâmicos e dois tipos de contato oclusais na distribuição de tensão de laminado cerâmico em incisivo central superior. Material e métodos: Modelos 3D foram realizados em software de modelagem contendo esmalte, dentina, polpa, simulador de ligamento periodontal e uma base de resina de poliuretano. Os desenhos foram modelados e exportados para o software de engenharia para realizar análise estatística estrutural. Para a malha, foram usados um total de 155429 elementos tetraedros e 271683 nós, após teste de convergência de 10\%. Dois materiais, dissilicato de lítio e cerâmica feldspática, foram simulados. Uma carga estática de $100 \mathrm{~N}$ em $45^{\circ}$ foi aplicada no terço incisal e médio na região palatina do dente, guiada pelo plano oclusal e a base foi restringida em todas as direções. A tensão de tração foi o critério de falha escolhido para a análise. Resultados: A análise de elementos finitos mostrou que os desenhos mais conservadores apresentaram menor concentração de tensão no laminado cerâmico. Contudo, as maiores concentrações de tensões foram observadas no laminado de dissilicato de lítio com preparo estendido no terço médio. O tipo de contato oclusal apresentou diferentes padrões de tensões entre os diferentes desenhos, o contato incisal mostrou maior concentração de tensão em relação ao contato do terço médio independentemente do material cerâmico. 
material. Conclusion: To perform a ceramic veneer in upper central incisor, the feldspathic ceramic presented promising results and should be recommended when the extended design was done. Regarding contact types, the incisal contact is more prone to failure regardless the ceramic and preparation design.

\section{KEYWORDS}

Ceramics; Dental veneers; Finite element analysis.
Conclusão: Para a confecção de laminado cerâmico em incisivo central superior, a cerâmica feldspática apresentou resultados promissores e é recomendada quando for feito preparo estendido. Em relação aos tipos de contato, o contato incisal é mais sujeito a falhas independentemente da cerâmica e desenho do preparo.

\section{PALAVRAS-CHAVE}

Cerâmicas; Laminados dentais; Análise de elemento finitos.

\section{INTRODUCTION}

$\mathrm{V}$ eneers are restorations indicate for anterior aesthetic rehabilitation. Usually, the materials select for this treatment are ceramics, because of the optical and mechanical properties, biocompatibility and color stability [1,2]. They are indicated to restore malformations, discolored teeth, fractures and dental diastemas [3-6]. A previous study [7] compared the survival rate between indirect resin composite and ceramic veneers and concluded that the performance is better using ceramic material. A retrospective study [8] of the clinical performance of porcelain veneers showed a survival probability of $97,6 \%$ after 7 years and $88,2 \%$ after 14 years. However, fracture, microleakage, debonding and secondary caries are still failures reported for this treatment modality [9].

The preparation design is an important factor for long-term success [1]. The literature present different preparation design without consensus which one is the most indicated $[10,11]$. Nevertheless, studies showed that veneers prepared in enamel have less chance to failure because of the high bond strength in the adhesive interface $[12,13]$. So, the minimally invasive treatment in recommended, though in some cases it is not possible. The choice of restorative material also modifies the restoration mechanical behavior [1,9]. The most suitable materials for veneers are feldspathic porcelain and lithium disilicate ceramic due to excellent esthetics, mechanical strength and because both materials enables the acid etching $[9,14]$.
A previous study [14] concluded that there is no difference when the preparation design is considered, but an increased in depth decreased the stress in restoration. Another report [15] however, concluded that the incisal bevel showed the best results with lower stress concentration, but they considered only one ceramic system (IPS e.max - lithium disilicate). Therefore, the present study aimed to compare the effect of two different restorative materials, four preparation designs and two different load incidences on the stress distribution of upper central incisor ceramic veneer.

\section{MATERIAL AND METHODS}

This study was approved by the local Institutional Review Board (754642) at the Institute of Science and Technology, São José dos Campos, São Paulo State University (UNESP).

The models were made following the BioCAD protocol [16]. A central upper left incisor was chosen by the Department of Anatomy and scanned to develop the geometric models with (Ceramill Map 100 Scaner, Amann Girrbach America Inc). The geometry of dentin and pulp was obtained from two periapical radiographs, (bucco-lingual and mesio-distal directions) and measured with ImageJ (Wayne Rasband, National Institute of Health). In this software, enamel thickness was measured for an accurate reproduction of the geometric model (Figure 1). 


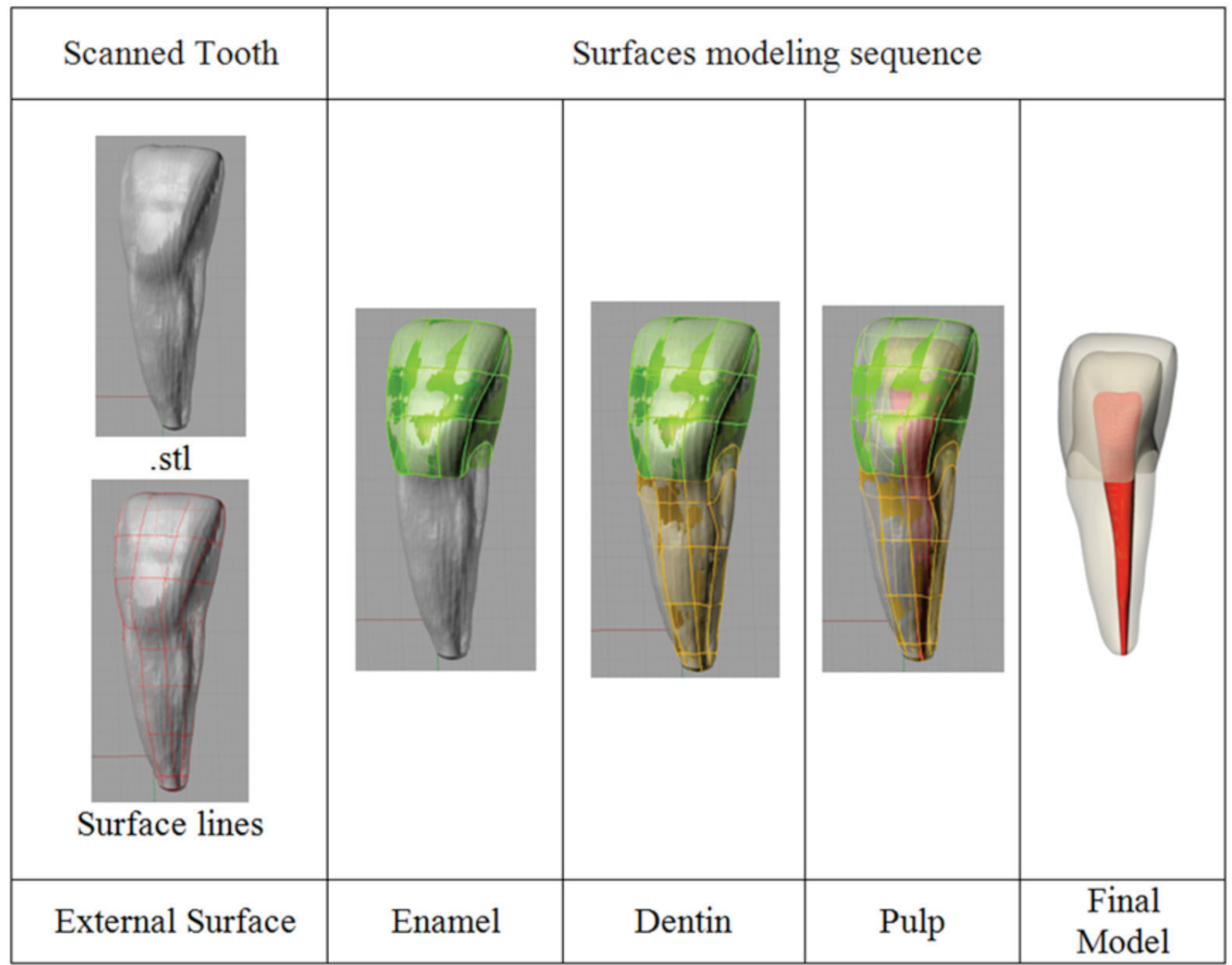

Figure 1- Surfaces modeling following the BIOCAD protocol.

The final geometry was embedded into a polyurethane cylinder by means of a polyether layer (simulating periodontal ligament). After, the model was replicated in different groups according to the veneer preparation design. Four different veneering designs (window, incisal reduction, incisal coverage and extended - palatal chamfer) were created simulating the clinical conditions of each case (Figure 2). The ceramic was then added on the worn surface. A perfectly bonding (shared nodes) condition was considered. 


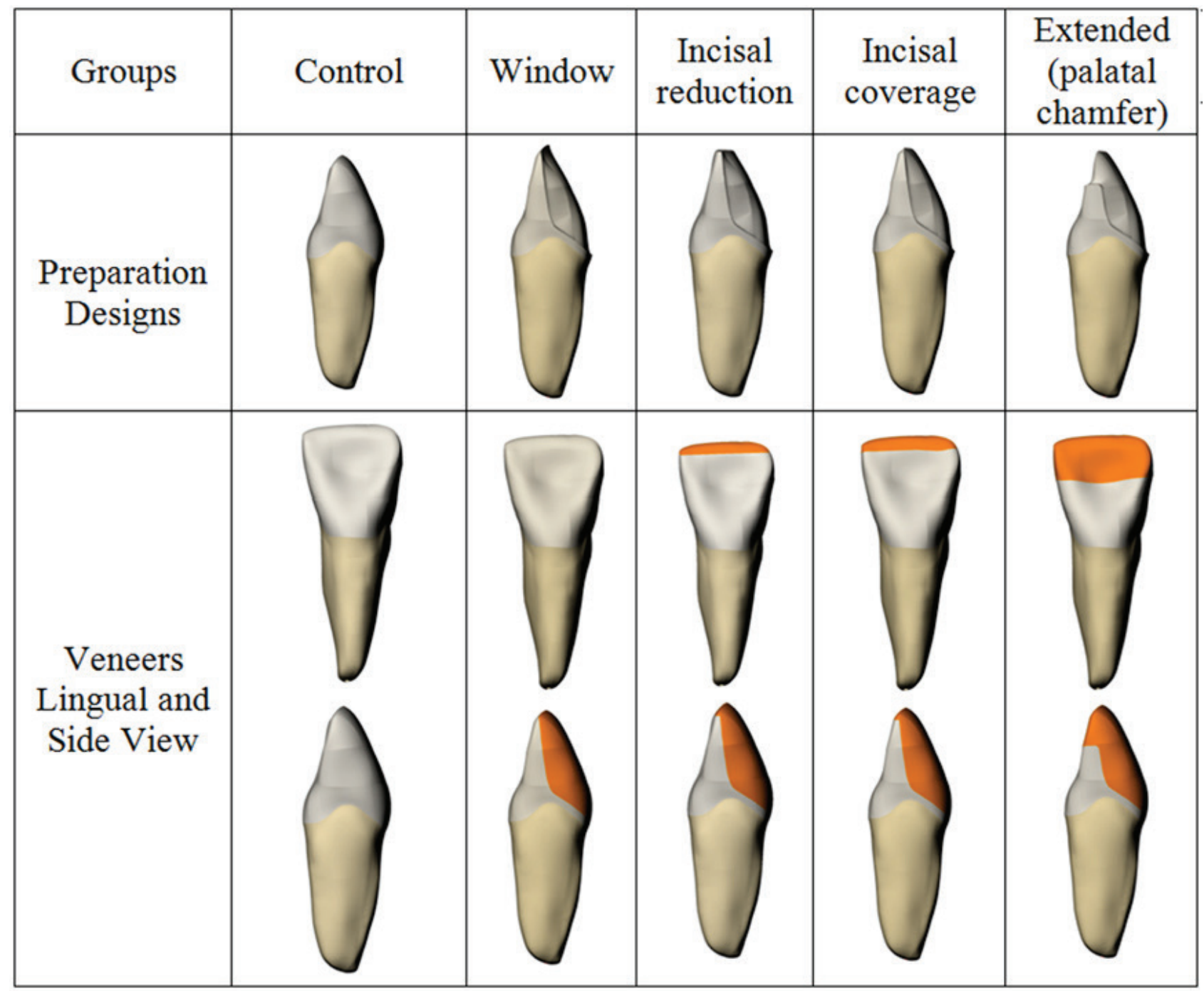

Figure 2 - Models created with preparations veneer designs - Lingual and mesial View.

After that, the geometries were exported in STEP format to analysis software (ComputerAided Engineering, ANSYS version 13.0; Ansys Inc., Canonsburg, PA). A controlled mesh was defined using 10-nodes-quadrilateral tetrahedral second order elements. The total finite element entities in the base model (control) were 271683 nodes and 155429 elements, nodes at interfaces were shared, and the relevance of all contact geometry was 50\% (Figure 3).
A $100 \mathrm{~N}$ load was applied to incisal edge center (protrusive contact - Figure 3), and at a point located in the middle third of palatal region (centric contact - Figure 3), at $45^{\circ}$ to the tooth occlusal plane [16]. The materials used were considered elastic, isotropic, homogeneous, continuous, and linear. 


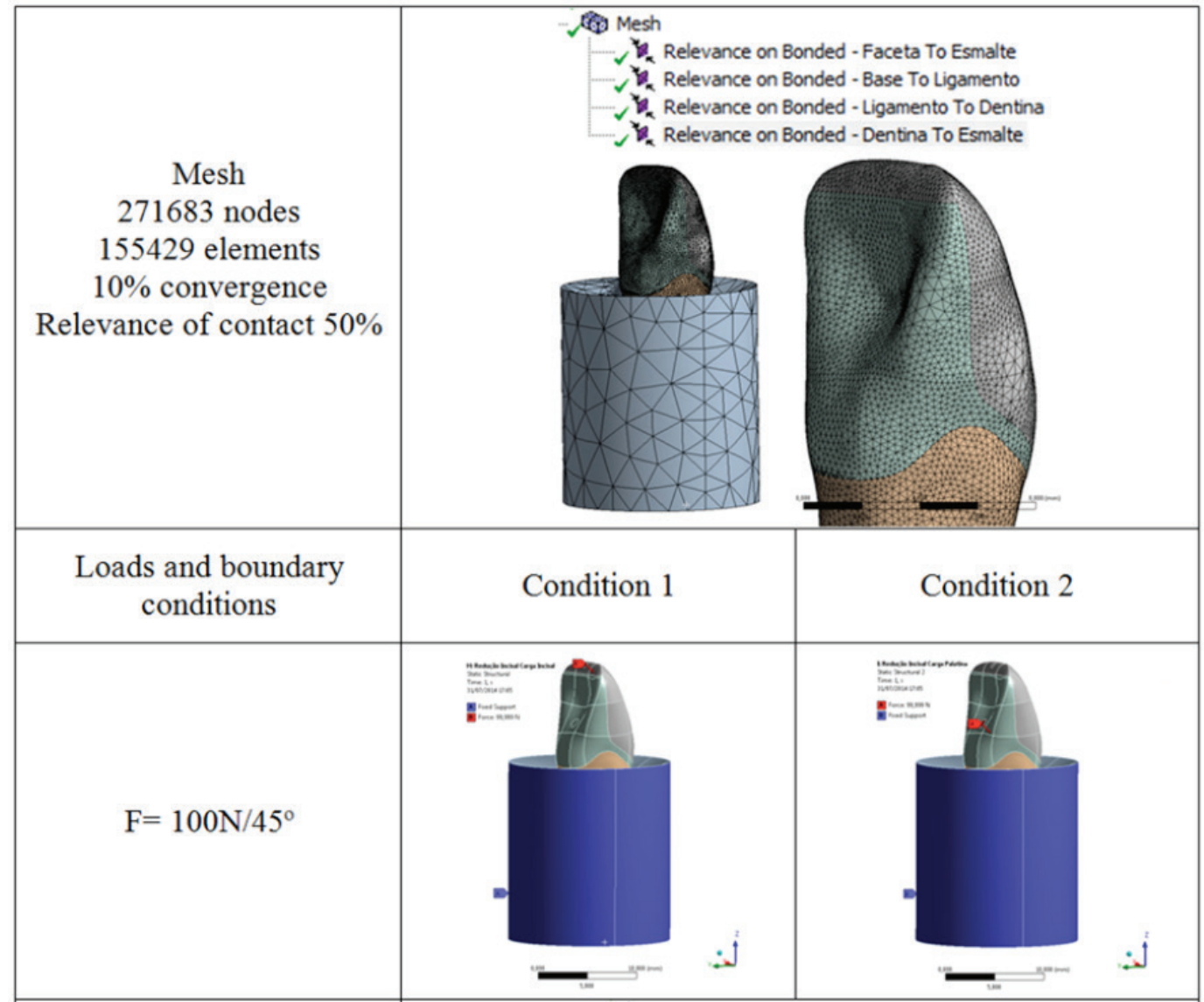

Figure 3 - FEM details - Mesh, boundary conditions, loads and connections.

The mechanical properties (Table I) were obtained from previous studies [17-21], except for polyurethane, which properties were obtained from direct measurement performed in laboratory, using natural frequencies (torsional and flexural) by impulse excitation technique, in order to determine the elastic module and Poisson's ratio (Sonelastic-ATCP Physical Engineering).

Table I - Materials mechanical properties

\begin{tabular}{|ccc|}
\hline Material & Elastic Modulus (GPa) & Poisson's Ratio \\
\hline Dentin & $18.6[17,18]$ & $0.32[19]$ \\
\hline Enamel & $84.1[18]$ & $0.33[19]$ \\
\hline Polyurethane* & 3.6 & 0.30 \\
\hline Polyether & $0.05[20]$ & $0.45[20]$ \\
\hline $\begin{array}{c}\text { Lithium Disilicate(IPSEm- } \\
\text { press I Ivoclar/Vivadent) }\end{array}$ & $\begin{array}{c}\text { Manufacturer's data } \\
\text { (Ivoclar/Vivadent) }\end{array}$ & $\begin{array}{c}\text { Manufacturer's data } \\
\text { (Ivoclar/Vivadent) }\end{array}$ \\
\hline Feldspathic(VM9-Vita) & $66.5[21]$ & $0.21[21]$ \\
\hline
\end{tabular}

* Direct measurement performed in laboratory, using Sonelastic (ATCP Physical Engineering).
The analysis criteria was the Maximum Principal Stress. Colorimetric maps, representing stress gradient on 3D model surfaces, were used to report the structural behavior qualitatively. The FEM results coherence analyses were performed by plotting the displacements and von Mises stress (Figure 4). 


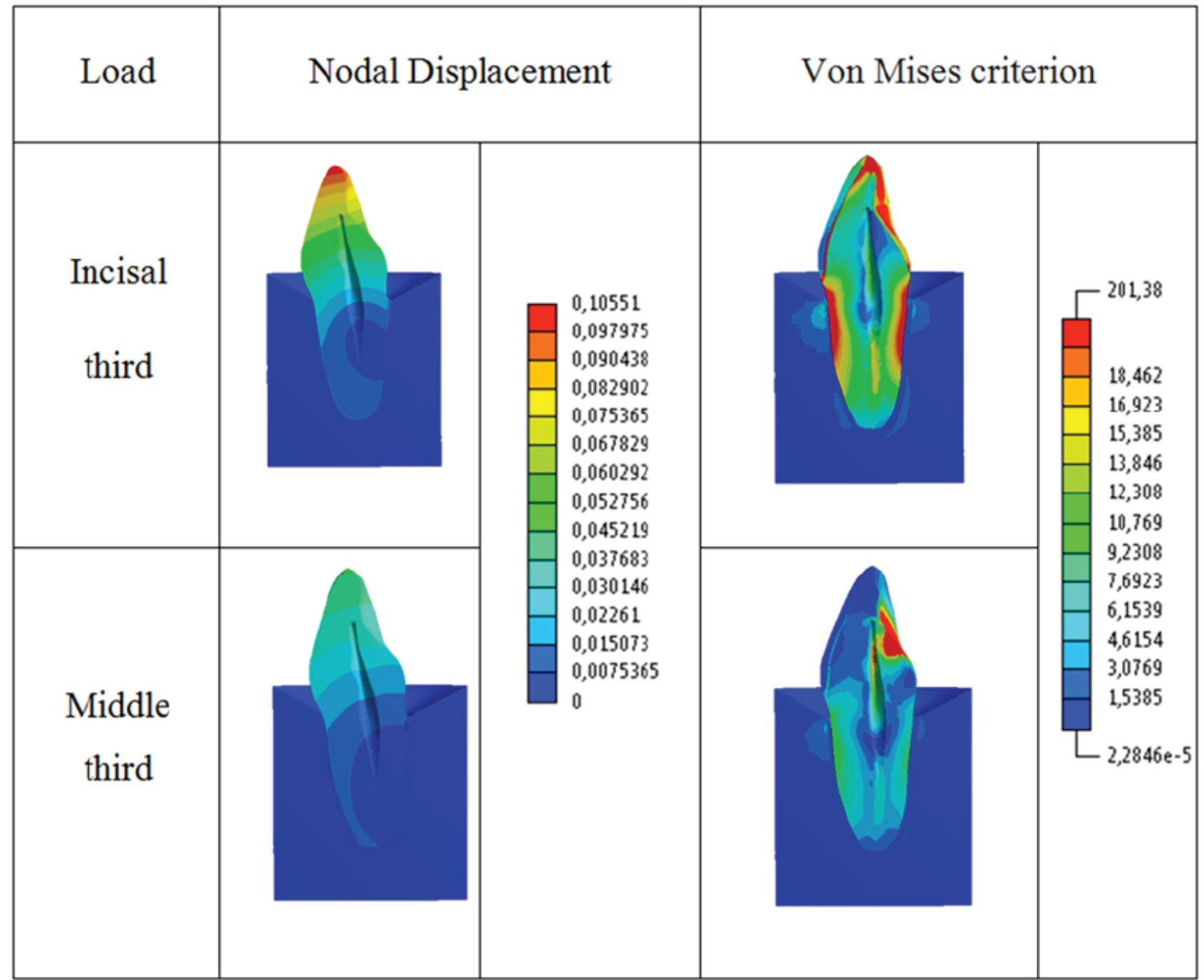

Figure 4 - Coherence Check - Nodal displacements and Von Mises Criteria.

\section{RESULTS}

In figure 4, the coherence results showed that there is no failure between the contacts or unnatural stress distribution. For tensile stress, it was observed, no significant difference on stress distribution, among the four preparation designs. However, for feldspathic ceramic model, loading the palatal middle third promoted lower stress concentration compared to the models subjected to loading on the incisal third (Figure 5). 


\begin{tabular}{|c|c|c|c|c|c|}
\hline \multirow{2}{*}{\multicolumn{2}{|c|}{ 仓̊ํํำ }} & \multicolumn{2}{|c|}{ Feldspathic } & \multicolumn{2}{|c|}{ Lithium disilicate } \\
\hline & & Incisal third & Middle third & Incisal third & Middle third \\
\hline & & & & & \\
\hline 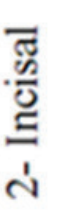 & 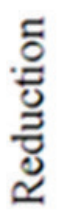 & & & & \\
\hline 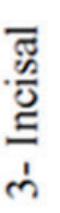 & 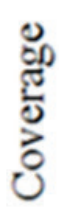 & & & & \\
\hline 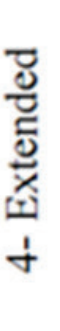 & 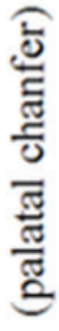 & & & & \\
\hline S0 & 20 & 16 & 10 & 5 & 10 \\
\hline
\end{tabular}

Figure 5 - Buccal view of the Maximum Principal Stress results regarding the restorative material and load incidence.

Figure 6 presents the palatal internal view. It was possible to observe that the stress concentration occurred near to the loading application point with different stress distributions on the veneer's intaglio surface (palatal chamfer).
However, the stress pattern was similar among all models within each material. Another important observation was the presence of large stress areas near the interface enamel/laminate veneer using lithium disilicate ceramic. 


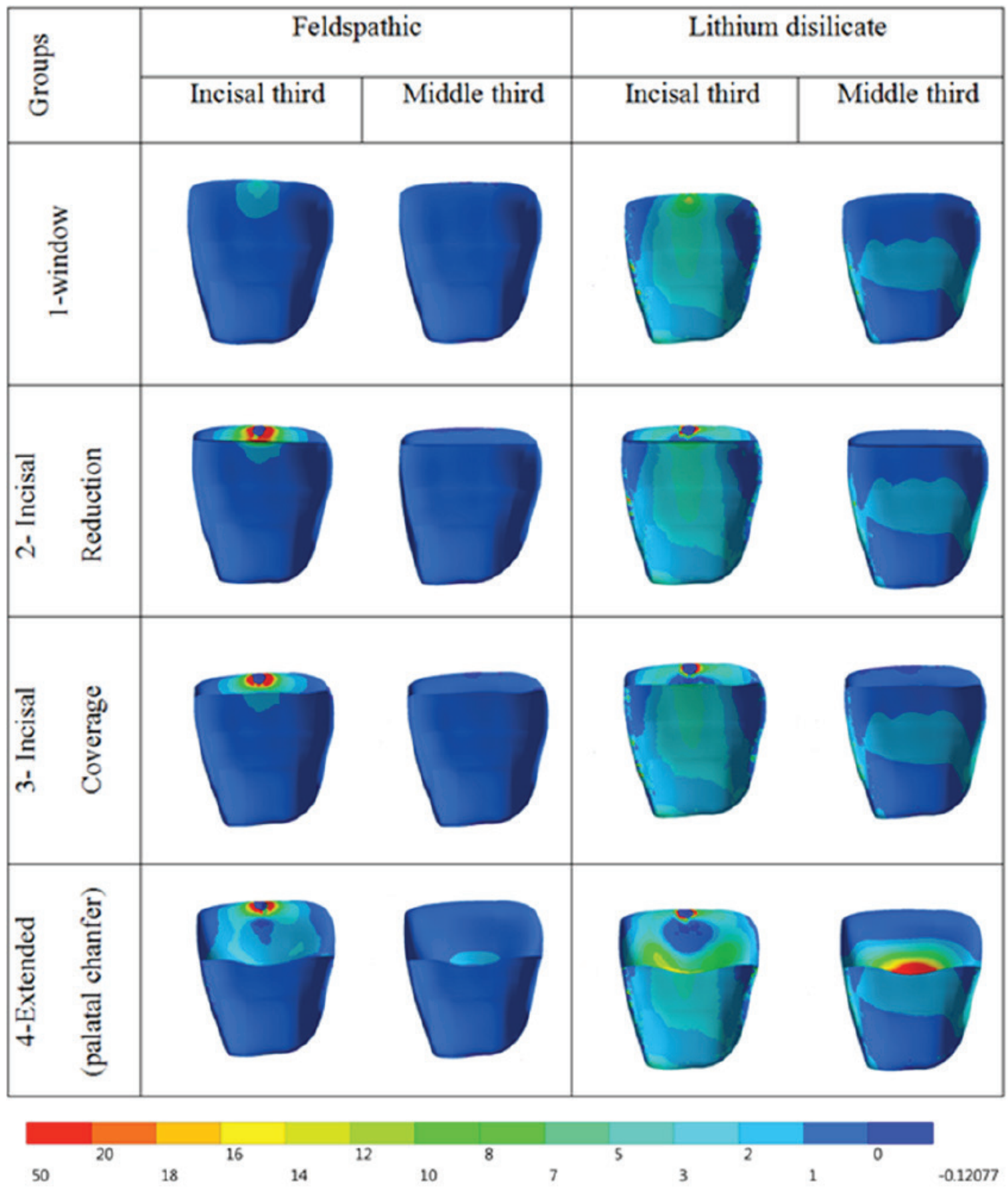

Figure 6 - Palatal view of the Maximum Principal Stress results regarding the restorative material and load incidence.

In a lateral view (Figure 7), for feldspathic ceramic veneers, which presents lower stiffness than enamel, load is transferred to veneer and abruptly migrated to tooth, therefore, leading to a lower stress magnitude (designs 2, 3, and 4). For lithium disilicate ceramic group, the extended preparation (design 4) presented the highest tensile stress in the chamfer. Regardless the ceramic material, the most conservative preparation designs showed less stress concentration (designs 1, 2 and 3). 


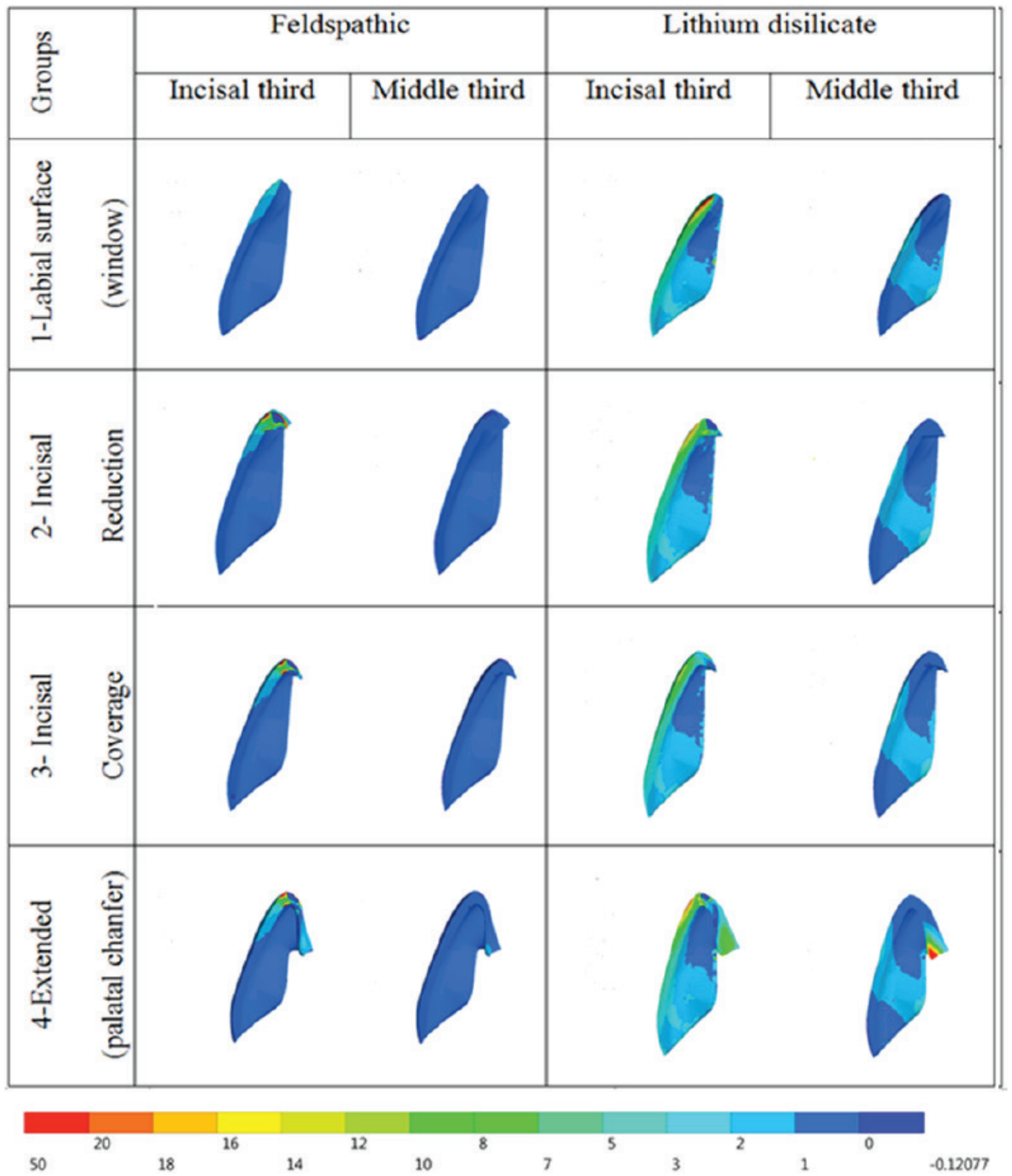

Figure 7 - Cross-sectioned lateral view of the Maximum Principal Stress results regarding the restorative material and load incidence.

\section{DISCUSSION}

The evaluation of the stress distribution in tooth may be very difficult due to a combination of complex geometry of different structures and materials; therefore, part of the studies in dental research have been based on 2-dimensional finite element analysis [22-26]. Bidimensional models may be acceptable when qualitatively investigating the biomechanical behavior under symmetrical conditions. However, 2D stress analysis is quantitatively less reliable due to 
difficult in represent the complex configuration of dental structures. The 3D models is considered a powerful and effective tool for visualization of the stress field in non-symmetric structures [1722,27-30].

All four preparations design for ceramic veneers simulated in the present study were restricted to enamel [31-35]. Tooth restored with cervical margins in dentin is reported to present significantly higher failure load if compared to those prepared with enamel margins [36]. Additionally, the preparation designs with marginal enamel provided an increase in the survival rate of restoration, if compared to margins in dentin [37].

In the present study, the tooth root and simulated supporting structures were included, because they are important when a more realistic analysis is necessary $[29,30,38]$. The resin cement layer was not simulated in this study once it was established a simplification hypothesis of bonded contact between the tooth and veneer. The linear behavior of models ensured that stress field was proportional to the applied load. However, any small changes in boundary conditions such as positioning of loading, fixation and even mesh quality/density, would significantly affect the results [34].

In the palatal view (Figure 6), it is possible to observe that a high stress concentration occurred near to the loading application points, especially when the loading is applied directly on veneer (incisal third). At loading region, the compressive stress is dominant, and therefore the maximum principal stress is close to zero (or negative). Immediately around load application, stresses have their sign reversed with tensile characteristics; this singularity is inherent of load application and the real stress distribution is hardly verified in a quantitative way considering the magnitude in this region. Additionally, the stress distribution was similar on the internal buccal surface (being far from load application point) for all models regardless the type of preparation design and material.

The results showed higher tensile stresses concentration in ceramic veneers for groups of extended preparation (palatal chamfer), suggesting those are more prone to cohesive failure of ceramic restorative materials, since stress concentration occurs precisely at the interface tooth/ceramic. Magne and Douglas [24] have claimed that long chamfers extending to the palatal concavity should be avoided, once thin porcelain extensions generate high tensile stress. Castelnuovo et al. [39] also found that veneers presenting feathered incisal edge or $2.0 \mathrm{~mm}$ of incisal reduction without palatal chamfer (butt joint) are more resistant to fracture. Seymour et al. [25] founded that stress within the porcelain were compressive with palatal loading and the tensile stresses were less with knife edge veneers margins compared with shoulders or chamfers. Bergoli et al. [23]. showed higher tensile stress concentration on laminate veneers for preparations with palatal chamfer.

On the other hand, FEM based works by Zarone et al. [40]; Chaiyabutr et al. [35] and Schmidt et al. [41], found unfavorable situations for veneers with more conservative preparation. The differences observed between the present study and Zarone's study [40] might be partially justified by the usage of Von Mises criterion for stress analysis instead of Maximum Principal Stress (Von Mises invariant does not differ tensile and compressive stress and it is recommended only for analysis of ductile materials, being not suitable for brittle materials such as porcelain). The findings from Chaiyabutr et al. [35] are based on fatigue failure and cannot be directly compared with the present study, in which static loads were performed. According to the experimental study by Schmidt et al. [41] extended preparation reduces the shear stresses by increasing the contact area of cement/tooth/ ceramic, thus preventing the displacement of veneer.

Li et al. [42] concluded employing palatal chamfer increases the preparation longevity. However, only for feldspathic ceramic. Indeed, the present study showed that the palatal preparation was effective if the ceramic is less stiff than enamel as feldspathic porcelain. It 
can be explained because, the higher the elastic modulus of restorative material the smaller the deformation of dental structures under the same stress [43].

The survival rate reported in the clinical study by Granel-Ruiz et al. [36] was $94 \%$ for more conservative preparations in comparison to $84.7 \%$ for palatal chamfer preparation, which led the authors to conclude that both preparations may be indicated for veneers restorations.

The protrusive movement (incisal contact) promotes higher stresses than occlusion in centric contact [40]. Moreover, the load angle application and masticatory loads are also responsible factors for increasing the potential of failure on teeth restored with ceramic veneers [44]. The combination of extensive restorative procedures and oblique occlusal loads significantly increases the chance of fractures [45].

\section{CONCLUSION}

Based in the results from the present study, the feldspathic and lithium disilicate based ceramic can be indicated to manufacture ceramic veneers however, if extended preparation design is necessary, the feldspathic ceramic should be preferred. The occlusal load in incisal third is more prone to failure regardless the material and preparation design.

\section{Acknowledgments}

The authors are grateful to CAPES for providing financial support.

\section{Funding}

This research received external funding of CAPES - Coordenação de Aperfeiçoamento de Pessoal de Nível Superior (Coordination for Advancement of Higher Education Personnel, Brazil)

\section{Conflict of interest}

The authors have no proprietary, financial, or other personal interest of any nature or kind in any product, service, and/or company that is presented in this article.

\section{Regulatory Statement}

This study was conducted in accordance with all the provisions of the local human subject's oversight committee guidelines and policies of Review Board at the Institute of Science and Technology, São José dos Campos, São Paulo State University (UNESP). The approval code for this study is: 754642

\section{REFERENCES}

1. Peumans M, Van Meerbeek B, Lambrechts P, Vanherle G. Porcelain veneers: a review of the literature. J Dent. 2000;28(3):163-77. doi:101016/s03005712(99)00066-4

2. Höland W, Schweiger M, Watzke R, Peschke A, Kappert H. Ceramics as biomaterials for dental restoration. Expert Rev Med Devices. 2008;5(6):72945. doi:10.1586/17434440.5.6.729

3. Belser UC, Magne P, Magne M. Ceramic laminate veneers: continuous evolution of indications. J Esthet Dent. 1997;9(4):197-207. doi:10.1111/j.1708-8240.1997.tb00941.x

4. Magne P, Perroud R, Hodges JS, Belser UC. Clinical performance of noveldesign porcelain veneers for the recovery of coronal volume and length. Int $\mathrm{J}$ Periodontics Restorative Dent. 2000;20(5):440-57.

5. Mozayek RS, Allaf M, Dayoub S. Porcelain sectional veneers, an ultraconservative technique for diastema closure (three-dimensional finite element stress analysis). Dent Med Probl. 2019;56(2):179-83. doi:10.17219/ $\mathrm{dmp} / 104602$

6. Vafiadis D, Goldstein $\mathrm{G}$. Single visit fabrication of a porcelain laminate veneer with CAD/CAM technology: a clinical report. J Prosthet Dent. 2011;106(2):713. doi:10.1016/S0022-3913(11)00100-4

7. Gresnigt MMM, Cune MS, Jansen K, van der Made SAM, Özcan M. Randomized clinical trial on indirect resin composite and ceramic laminate veneers: Up to 10-year findings. J Dent. 2019;86:102-9. doi:101016/j. jdent.2019.06.001

8. Arif R, Dennison JB, Garcia D, Yaman P. Retrospective evaluation of the clinical performance and longevity of porcelain laminate veneers 7 to 14 years after cementation. J Prosthet Dent. 2019;122(1):31-7. doi:10.1016/j. prosdent.2018.09.007

9. Penteado MM, Mendes Tribst JP, Dal Piva AMO, Archangelo KC, Bottino MA Souto Borges AL. Influence of different restorative material and cement on the stress distribution of ceramic veneer in upper central incisor. Indian J DentRes. 2020;31(2):236-40. doi:10.4103/ijdr.IJDR_150_18

10. da Costa DC, Coutinho M, de Sousa AS, Ennes JP. A meta-analysis of the most indicated preparation design for porcelain laminate veneers. J Adhes Dent. 2013;15(3):215-20. doi:10.3290/j.jad.a29587

11. Hong N, Yang H, Li J, Wu S, Li Y. Effect of preparation designs on the prognosis of porcelain laminate veneers: a systematic review and metaanalysis. Oper Dent. 2017;42(6):E197-E213. doi:10.2341/16-390-L

12. Jurema ALB, Penteado MM, Tribst JPM, Caneppele TMF, Borges ALS. Effect of glass-fiber post on the biomechanical behavior of teeth with direct veneers. Brazi Dent Sci. 2020;23(3);1-7. 
13. Blunck U, Fischer S, Hajtó J, Frei S, Frankenberger R. Ceramic laminate veneers: effect of preparation design and ceramic thickness on fracture resistance and marginal quality in vitro. Clin Oral Investig. 2020;24(8):274554. doi:10.1007/s00784-019-03136-z

14. Tsouknidas A, Karaoglani E, Michailidis N, Kugiumtzis D, Pissiotis A Michalakis K. Influence of preparation depth and design on stress distribution in maxillary central incisors restored with ceramic veneers: $\mathrm{a} 3 \mathrm{D}$ finite element analysis. J Prosthodont. 2020;29(2):151-60. doi:10.1111/jopr.13121

15. Ustun 0, 0zturk AN. The evaluation of stress patterns in porcelain laminate veneers with different restoration designs and loading angles induced by functional loads: A three-dimensional finite element analysis study. Niger J Clin Pract. 2018;21(3):337-42. doi:10.4103/njcp.njcp45 17

16. Noritomi P,Xavier T, Silva J. A comparison between BioCAD and some know methods for finite element model generation. 5th Advanced Research in Virtual and Rapid Prototyping;201228 Sep-010ctober; Leiria, Portugal. In: Bártolo P.et al, ed. Innovative developments in virtual and physical prototyping. Balkema, Leiden:CRC Press; 2012. p.685-90.

17. Ko CC, Chu CS, Chung KH, Lee MC. Effects of posts on dentin stress distribution in pulpless teeth. J Prosthet Dent. 1992;68(3):421-7. doi:10.1016/0022-3913(92)90404-x

18. Sano H, Ciucchi B, Matthews WG, Pashley DH. Tensile properties of mineralized and demineralized human and bovine dentin. J Dent Res. 1994;73(6):1205-11. doi:10.1177/00220345940730061201

19. Farah JW, Craig RG, Meroueh KA. Finite element analysis of three- and fourunit bridges. J Oral Rehabil. 1989;16(6):603-11. doi:10.1111/j.1365-2842.1989. tb01384.x

20. Farah JW, Clark AE, Ainpour PR. Elastomeric impression materials. Oper Dent. 1981;6(1):15-9. PMID: 6941224

21. Borba M, de Araúijo MD, de LimaE, Yoshimura HN, Cesar PF, Griggs JA, et al. Flexural strength and failure modes of layered ceramic structures. Dent Mater.2011Dec;27(12):1259-66. doi: 10.1016/j.dental.2011.09.008

22. Della Bona A, van Noort R. Shear vs. tensile bond strength of resin composite bonded to ceramic. J Dent Res. 1995;74(9):1591-6. doi:10.1177/0022034595 0740091401

23. Bergoli CD, Meira JB, Valandro LF, Bottino MA. Survival rate, load to fracture, and finite element analysis of incisors and canines restored with ceramic veneers having varied preparation design. Oper Dent. 2014;39(5):530-40. doi:10.2341/13-179

24. Magne P,Douglas WH. Design optimization and evolution of bonded ceramics for the anterior dentition: a finite-element analysis. Quintessence Int. 1999:30(10):661-72.

25. Seymour KG, Cherukara GP, Samarawickrama DY. Stresses within porcelain veneers and the composite lute using different preparation designs. J Prosthodont. 2001;10(1):16-21. doi:10.1111/.1532-849x.2001.00016.x

26. Al-huwaizi HF. A finite element analysis of the effect of different margin designs and loading positions on stress concentration in porcelain veneers. JColl Dent. 2005;17:8-12.

27. Sorensen JA, Cruz M, Mito WT, Raffeiner O, Meredith HR, Foser HP. A clinical investigation on three-unit fixed partial dentures fabricated with a lithium disilicate glass-ceramic. Pract Periodontics Aesthet Dent. 1999;11(1):95-108.

28. Magne P, Versluis A, Douglas WH. Rationalization of incisor shape: experimental-numerical analysis. J Prosthet Dent. 1999;81(3):345-55 doi:10.1016/s0022-3913(99)70279-9
29. Rees JS. An investigation into the importance of the periodontal ligament and alveolar bone as supporting structures in finite element studies. J Oral Rehabil. 2001;28(5):425-32. doi:10.1046/:1365-2842.2001.00686.x

30. Ausiello P, Ciaramella S, De Benedictis A, Lanzotti A, Tribst JPM, Watts $\mathrm{DC}$. The use of different adhesive filling material and mass combinations to restore class II cavities under loading and shrinkage effects: a 3D-FEA. Comput Methods Biomech Biomed Engin. 2020;22:1-11. doi: 10.1080/10255842.2020.1836168.

31. Costa VLS, Tribst JPM, Uemura ES, de Morais DC, Borges ALS. Influence of thickness and incisal extension of indirect veneers on the biomechanical behavior of maxillary canine teeth. Restor Dent Endod. 2018;43(4):e48. doi:10.5395/rde.2018.43.e48

32. de Andrade GS, Tribst JP, Dal Piva A0, Bottino MA, Borges AL, Valandro LF, et al. A study on stress distribution to cement layer and root dentin for post and cores made of CAD/CAM materials with different elasticity modulus in the absence of ferrule. J Clin Exp Dent. 2019 Jan 1;11(1):e1-e8. doi:10.4317/ jced.55295.

33. Akoğlu B, Gemalmaz D. Fracture resistance of ceramic veneers with different preparation designs. J Prosthodont. 2011;20(5):380-4. doi:10.1111/ j.1532-849X.2011.00728.x

34. Lisiak-Myszke M, Marciniak D, Bieli ski M, Sobczak H, Garbacewicz Ł, Drogoszewska B. Application of Finite Element Analysis in Oral and Maxillofacial Surgery-A Literature Review. Materials. 2020 Jul 9;13(14):3063. doi: 10.3390/ma13143063.

35. Chaiyabutr Y,Phillips KM, Ma PS, Chitswe K. Comparison of load-fatigue testing of ceramic veneers with two different preparation designs. Int J Prosthodont. 2009;22(6):573-5.

36. Granell-Ruiz M, Fons-Font A, Labaig-Rueda C, Martínez-González A, RománRodríguez JL, Solá-Ruiz MF. A clinical longitudinal study 323 porcelain laminate veneers. Period of study from 3 to 11 years. Med Oral Patol Oral Cir Bucal. 2010;15(3):e531-e7.doi:10.4317/medoral.15.e531

37. Cötert HS, Dündar M, Oztürk B. The effect of various preparation designs on the survival of porcelain laminate veneers. J Adhes Dent. 2009;11(5):405-11.

38. Sorrentino R, Apicella D, Riccio C, Gherlone E, Zarone F, Aversa R, et al. Nonlinear visco-elastic finite element analysis of different porcelain veneers configuration. J Biomed Mater Res B Appl Biomater. 2009 Nov;91(2):727-36. doi: 10.1002/jbm.b.31449

39. Castelnuovo J, Tjan AH, Phillips K, Nicholls Jl, Kois JC. Fracture load and mode of failure of ceramic veneers with different preparations. J Prosthet Dent. 2000;83(2):171-80. doi:10.1016/s0022-3913(00)80009-8

40. Zarone F, Apicella D, Sorrentino R, Ferro V, Aversa R, Apicella A. Influence of tooth preparation design on the stress distribution in maxillary central incisors restored by means of alumina porcelain veneers: $\mathrm{a} 3 \mathrm{D}$-finite element analysis. Dent Mater. 2005;21(12):1178-88. doi:10.1016/j.dental.2005.02.014

41. Schmidt KK, Chiayabutr Y,Phillips KM, Kois JC. Influence of preparation design and existing condition of tooth structure on load to failure of ceramic laminate veneers. J Prosthet Dent. 2011;105(6):374-82. doi:10.1016/S00223913(11)60077-2

42. LiZ, Yang Z,Zuo L, Meng Y.A three-dimensional finite element study on anterior laminate veneers with different incisal preparations. J Prosthet Dent. 2014;112(2):325-33. doi:10.1016/j.prosdent.2013.09.023

43. Magne P,Belser UC. Porcelain versus composite inlays/onlays: effects of mechanical loads on stress distribution, adhesion, and crown flexure. Int $\mathrm{J}$ Periodontics Restorative Dent. 2003;23(6):543-55. 
Influence of Preparation Design, Restorative Material and Load Direction on The Stress Distribution of Ceramic Veneer in Upper Central Incisor

44. Chander NG, Padmanabhan TV. Finite element stress analysis of diastema closure with ceramic laminate veneers. J Prosthodont. 2009;18(7):577-81. doi:10.1111/j.1532-849X.2009.00490.x
45. Tribst JPM, Dal Piva AMO, de Jager N, Bottino MA, de Kok P, Kleverlaan CJ. Full-Crown Versus Endocrown Approach: A 3D-Analysis of Both Restorations and the Effect of Ferrule and Restoration Material. J Prosthodont. 2020; 28: 1-10. doi: 10.1111/jopr.13244.

\section{Fernanda Zapater Pierre}

(Corresponding address)

São Paulo State University (UNESP), Institute of Science and Technology, Department

of Restorative Dentistry, São José dos Campos, São Paulo, Brazil.

Email: fernanda.pierre@unesp.br 